\title{
Борьба с антисемитизмом в Европе: готова ли ОБСЕ к вызову?
}

\author{
Раввин Эндрю Бейкер*
}

\section{Аннотация}

Данная статья посвящена двум наиболее общепризнанным и давним вызовам, с которыми сталкивается ОБСЕ в борьбе с антисемитизмом: проблемам безопасности еврейских общин и важности общего и всеобъемлющего определения антисемитизма. Опираясь на личный опыт автора в качестве личного представителя действующего Председателя ОБСЕ по борьбе с антисемитизмом, в ней исследуются ключевые поворотные моменты в подходе ОБСЕ к борьбе с антисемитизмом, рассматриваются проблемы, связанные с организационной структурой ОБСЕ, финансированием и принципами принятия решений в ОБСЕ, и, наконец, высказываются соображения относительно возможностей восстановления лидирующей роли ОБСЕ в борьбе с антисемитизмом в будущем.

\section{Ключевые слова}

ОБСЕ, БДИПЧ, антисемитизм, терроризм, безопасность еврейских общин

Для цитирования этой публикации: Бейкер Р. Э. Борьба с антисемитизмом в Европе: готова ли ОБСЕ к вызову? // ОБСЕ Insights 2. - Баден-Баден: Номос, 2021. URL: https://doi.org/10.577 1/9783748921264-02

\section{Введение}

Солнечным апрельским днем 2004 г. я направлялся в немецкую канцелярию. Рядом со мной шел посол Кристиан Штрохал, директор Бюро по демократическим институтам и правам человека (БДИПЧ). Конференция ОБСЕ высокого уровня по проблемам антисемитизма ${ }^{43}$ только что завершилась, и мы направились на заключительный прием, устроенный канцлером Германии Герхардом Шредером. По общему мнению, конференция стала важной вехой в усилиях, направленных на то, чтобы побудить ОБСЕ заняться проблемой возрождения антисемитизма в Европе.

На заседаниях председательствовали министр иностранных дел Германии Йошка Фишер и действующий Председатель ОБСЕ в 2004 году, министр иностранных дел Болгарии Соломон Пасси. Многие государства-участники были представлены на таком же высоком уровне. За год до этого я тесно сотрудничал с послом США в

* Раввин Эндрю Бейкер, Представительство действующего Председателя ОБСЕ по борьбе с антисемитизмом, bakera@ajc.org 
ОБСЕ Стивом Миникесом в усилиях, направленных на то, чтобы убедить организацию провести первую конференцию, посвященную антисемитизму, которая состоялась затем в Вене в июне 2003 года. На тот момент это определенно поставило проблему антисемитизма в повестку дня ОБСЕ, но не было уверенности, будут ли предприняты какие-либо дальнейшие шаги, пока немецкая делегация не объявила на заключительном заседании, что Берлин примет у себя вторую конференцию.

Теперь у нас были эта конференция 2004 года и важная Берлинская декларация 44 , которая была принята по ее завершении. «Берлинская декларация» 2004 г. поручила БДИПЧ «внимательно отслеживать инциденты антисемитского характера в регионе ОБСЕ, используя при этом всю имеющуюся и заслуживающую доверия информацию». Ему было также поручено «систематически собирать и распространять в масштабах всего региона ОБСЕ информацию о лучшей практике предупреждения антисемитизма и противодействия ему, а также оказывать государствам-участникам по их просьбе консультационные услуги в борьбе с антисемитизмом» ${ }^{45}$.

Естественно, я был взволнован таким исходом, но у Кристиана Штрохала было кислое выражение лица. «Легко дать нам больше обязанностей», - сказал он мне тогда. «Но окажет ли нам кто-нибудь необходимую поддержку для их выполнения?»

Берлинская конференция и декларация привели к тому, что проблеме антисемитизма стало уделяться все больше внимания и были предприняты реальные усилия по ее решению. В некотором роде ОБСЕ имела для этого уникальные возможности. Борьба с антисемитизмом прямо вписывается в ее мандат в области человеческого измерения. Соединенные Штаты, один из самых сильных голосов, призывающих к более активным мерам, сидели за одним столом с европейскими правительствами. Принятые в рамках ОБСЕ обязательства, несмотря на то, что они не носили юридически обязывающего характера, были серьезно восприняты теми государствамиучастниками, где проблема антисемитизма стояла наиболее остро. Можно с уверенностью утверждать, что продолжительные внутренние дискуссии относительно конкретных формулировок «Берлинской декларации» напрямую отразили понимание того, что слова имеют значение, и государства будут прислушиваться к ним.

Всего через несколько недель после Берлинской конференции ОБСЕ Европейский центр мониторинга расизма и ксенофобии (ЕЦМРК) выпустил свой первый отчет об антисемитизме в Европейском Союзе ${ }^{46}$. Отчет состоял из двух частей. Одна из них основывалась, главным образом, на ограниченных данных, полученных из оперативных сводок об инцидентах и опросов общественного мнения, собранных наблюдателями ЕЦМРК в государствах-участниках. Вторая часть представляла собой компиляцию интервью с лидерами европейских еврейских общин. Эти интервью обрисовали пессимистическую картину, свидетельствующую об уровне тревоги, который не наблюдался десятилетиями. Ссылаясь на рост числа антисемитских инцидентов и слабую реакцию правительств, некоторые даже ставили под сомнение будущее еврейской общинной жизни. Сам ЕЦМРК также указал, что его наблюда- 
телям мешает отсутствие какого-либо определения антисемитизма (в большинстве случаев), а также отсутствие общего определения (в остальных случаях $)^{47}$.

В данной статье я остановлюсь на некоторых ключевых поворотных моментах в подходе ОБСЕ к борьбе с антисемитизмом, в первую очередь на двух наиболее известных и давних вызовах: проблемах безопасности еврейских общин и важности использования общего и исчерпывающего определения антисемитизма. Затем я рассмотрю конкретный контекст ОБСЕ, где организационные факторы, такие как финансирование, принятие решений и принцип консенсуса также представляют собой вызов, а впоследствии представлю возможности нового председательства по восстановлению ведущей роли ОБСЕ в борьбе с антисемитизмом.

\section{К вопросу о проблемах безопасности еврейских общин}

В феврале 2020 года албанское председательство в ОБСЕ провело в Тиране конференцию по борьбе с антисемитизмом в регионе ОБСЕ. Оно продолжило традицию проведения таких конференций в начале года, начатую итальянским Председателем в 2018 году и продолженную словацким Председателем в 2019 году. В Тиранской конференции, организованной при сотрудничестве БДИПЧ, в частности, приняли участие члены Парламентской ассамблеи ОБСЕ и Верховный комиссар ОБСЕ по делам национальных меньшинств, а также представители других международных организаций, государств-участников и гражданского общества. На конференции были предложены рекомендации, адресованные всем заинтересованным сторонам. Спустя всего две недели после конференции Парламентская ассамблея ОБСЕ организовала на своем зимнем совещании в Вене специальную сессию для парламентариев с целью обсуждения проблемы антисемитизма.

Мы ожидали, что в течение года появятся дополнительные возможности проследить за выполнением этих рекомендаций на дополнительных совещаниях по вопросам человеческого измерения, заседаниях Постоянного совета и запланированных визитах личных представителей в государства-участники. Возобновление активного участия Парламентской ассамблеи, резолюции которой предваряли первые конференции ОБСЕ по антисемитизму, добавило бы еще одного ценного сторонника. К сожалению, пандемия коронавируса внезапно внесла коррективы в эти планы. Несмотря на то, что важные встречи по выполнению обязательств в области человеческого измерения могут проходить в онлайн формате на платформе Зум, оказалось невозможным провести ставшие их составной частью параллельные мероприятия и неформальные встречи организаций гражданского общества и государств-участников.

Данные об антисемитских инцидентах за прошедшие годы и в течение 2019 года, как правило, свидетельствуют о нарастании или по крайней мере об отсутствии спада в их интенсивности ${ }^{48}$. Некоторые колебания могут быть связаны с изменениями в 
отчетности и сборе данных. Когда будут представлены данные за 2020 г., эксперты предвидят уменьшение числа физических инцидентов, что объясняется тем фактом, что в связи с пандемией COVID-19 были закрыты школы и синагоги, а большинство людей оставалось дома. Но это никого не успокаивает. Мы стали свидетелями распространения антисемитизма и теорий заговора, связывающих евреев с коронавирусом во всех социальных сетях. Мы знаем, что пандемия будет иметь долгосрочные экономические последствия. Когда нормальная жизнь вернется в наши города, мы должны ожидать, что антисемитизм вернется на улицы. Во всяком случае, сейчас самое время для того, чтобы усилить нашу подготовку в области безопасности и подготовку к борьбе с ним.

В 2009 году и в последующие годы мне в качестве личного представителя действующего Председателя ОБСЕ по вопросам борьбы с антисемитизмом была предоставлена возможность ставить этот вопрос в ходе официальных визитов в государства-участники ${ }^{49}$. Сначала я встречался с лидерами и представителями еврейских общин и основных организаций гражданского общества, а затем - с представителями властей. Важным элементом этих визитов была оценка потребностей и проблем еврейских общин в области безопасности, а также мер, которые в этой связи предпринимают правительства. Несмотря на то, что в каждой стране ситуация была особой, западноевропейские еврейские общины, как правило, сталкивались с двумя типами угроз. Они были мишенью для радикальных исламистских экстремистов, которые развернули международную террористическую деятельность, - и поэтому у них были основания опасаться за свою жизнь. Кроме того, они регулярно становились жертвами словесных оскорблений и физического насилия, которые подрывали комфорт и безопасность их повседневной жизни.

В то время я поднял этот вопрос, и государства-участники признали, что антисемитизм реален, а опасения по поводу безопасности - оправданны. Однако это не обязательно означало, что предпринимались надлежащие меры для решения этих проблем. На самом деле, на встречах с правительственными чиновниками я был удивлен и разочарован царящим бездействием и его различными оправданиями. В качестве иллюстрации, на встречах с голландскими чиновниками в Гааге мне сказали, что правительство не может обеспечить усиленную безопасность синагог, не предоставив такие же меры безопасности церквям и мечетям, даже если эти другие культовые здания не сталкивались с аналогичными проблемами безопасности. Не имея необходимых средств, чтобы обеспечить подобные меры повсюду, они нигде их не обеспечивали, и еврейские общины по праву чувствовали себя заброшенными.

Власти Бельгии сказали мне, что, по их мнению, здания еврейской общины в Брюсселе подвергаются той же степени угрозы, что и посольство Израиля. Но они признали, что у них не хватало бюджетных средств для принятия мер по обеспечению безопасности синагог и еврейских школ, которые они сами считали необходимыми. 
В Дании еврейская община Копенгагена попросила обеспечить видимое присутствие полиции перед общинным центром и школами во время наибольшего скопления там людей, однако ей было отказано в этом. Когда я обратился с этой просьбой к правительственным чиновникам, мне сказали, что размещение вооруженной полиции перед зданиями не является обычной практикой, и это, скорее всего, вызовет беспокойство у всего населения. По их расчетам, это превысит реальную потребность еврейской общины в безопасности. Через пять месяцев после моего визита безоружный охранник еврейской общины был убит в результате теракта перед копенгагенской синагогой.

Во время моей первой поездки в Швецию я узнал, что еврейская община Стокгольма тратит четверть своего бюджета на обеспечение безопасности. Во время следующей поездки мне сообщили, что правительство отреагировало на эту проблему, выделив каждой религиозной общине фиксированную сумму денег на меры по повышению безопасности. Однако несмотря на то, что еврейская община Стокгольма централизовала свою школу и большинство общинных мероприятий в недавно открывшемся здании в центре города, этот центр общинной деятельности имел право на помощь в том же размере, что и отдельная церковь или синагога.

Конечно, есть и другие примеры, но все они иллюстрируют существенный разрыв между потребностями еврейских общин в безопасности и ограниченным пониманием и помощью, которые они получают от правительств своих стран. Несмотря на то, что ОБСЕ была не единственной организацией, которая занималась этим вопросом, краткий обзор того, как ОБСЕ, БДИПЧ, государства-участники и группы гражданского общества объединили свои усилия для решения этой проблемы, демонстрирует уникальную роль, которую играла ОБСЕ.

19 марта 2012 года исламский террорист совершил нападение на еврейскую школу в Тулузе (Франция) и зверски убил учителя и трех маленьких детей. Перед этим тот же террорист совершил два нападения и застрелил четырех французских военнослужащих-мусульман. До того, как личность террориста была установлена, правоохранительные органы предполагали, что он действовал, руководствуясь правыми, ультранационалистическими убеждениями. Эти убийства вызвали широкий общественный резонанс. Но когда он был найден и окружен полицией, и когда вскрылась правда о его мотивах, некоторая часть солидарности с еврейской общиной исчезла.

Французская еврейская община имеет хорошо функционирующую организацию по обеспечению безопасности, которая провела свое собственное расследование. Школы были особенно уязвимы в начале дня, когда родители и дети приходят и уходят, и даже охраняемые входные двери могут быть оставлены открытыми. Камеры наблюдения показали, что террорист сначала осмотрел школу утром того же дня, перед тем как совершить нападение, но те, кто жил поблизости, не заметили подозрительного поведения или не сообщили об этом. Лидеры общины не были уверены в том, что стоит делиться подробностями нападения, которые были на- 
столько ужасающими, но все же продемонстрировали бы, насколько обоснованы их опасения.

Как личный представитель я предложил действующему Председателю организовать конференцию по безопасности еврейских общин. Несмотря на поддержку такой конференции, потребовалось несколько месяцев, прежде чем были созданы все необходимые условия. Украинское председательство в ОБСЕ в 2013 году согласилось включить вопрос безопасности еврейских общин в свою программу. Правительство Германии предложило принять конференцию у себя, а министр внутренних дел Германии д-р Ханс-Петер Фридрих согласился выступить с основным докладом. Мы сформировали комитет по планированию, в который вошли представители ключевых организаций гражданского общества (Европейский еврейский конгресс, Американский еврейский комитет в Берлине, Центральный совет евреев в Германии), начальник департамента БДИПЧ по вопросам толерантности и недискриминации (ТНД), а также официальные лица Германии. В июне 2013 г. в Берлине состоялась конференция «Обеспечение потребностей еврейских общин в сфере безопасности в регионе ОБСЕ: вызовы и хорошая практика» ${ }^{50}$. В частности, на конференции были представлены совместные презентации руководителей служб безопасности еврейских общин вместе с их соответствующими правительственными и правоохранительными партнерами из четырех ключевых государств-участников. Они изложили стоящие перед ними проблемы и привели примеры сотрудничества по их решению. На основании этих примеров и других выступлений были выработаны всесторонние рекомендации, содержащиеся в докладе конференции.

В следующем году Михаэль Георг Линк занял пост директора БДИПЧ ОБСЕ. Как бывший госсекретарь министерства иностранных дел Германии, он был хорошо осведомлен об этой конференции, ее рекомендациях и той поддержке, которую оказало правительство Германии. В ноябре 2014 г. в Берлине состоялась конференция «Берлин плюс десять», которая предоставила возможность правительствам и гражданскому обществу рассмотреть проблему антисемитизма в регионе ОБСЕ через десять лет после принятия «Берлинской декларации» 51 . В своих заключительных замечаниях швейцарское председательство особо призвало «правоохранительные органы бороться с очень реальными угрозами безопасности еврейских общин» ${ }^{52}$. Директор Линк изложил амбициозный план по решению проблемы растущего антисемитизма в регионе ОБСЕ с акцентом на особые проблемы безопасности, стоящие перед еврейскими общинами. Директор и сотрудники БДИПЧ разработали подробный внебюджетный проект под названием «От слов к делу в борьбе с антисемитизмом». Правительство Германии согласилось предоставить значительные средства, необходимые для реализации этого проекта.

Для управления и развития проекта «От слов к делу» БДИПЧ нанял дополнительных сотрудников. Они, в свою очередь, провели несколько встреч с экспертами из государств-участников и представителями еврейских общин, которые имели непосредственный опыт в решении вопросов безопасности и, таким образом, могли обо- 
значить особые проблемы, лучшую практику и необходимые правительственные меры. В результате было опубликовано практическое руководство «Понимание сути преступлений на почве антисемитизма и обеспечение потребностей еврейских общин в сфере безопасности» ${ }^{53}$.

В руководстве разъясняется проблема антисемитизма и даются инструкции государствам-участникам и правоохранительным органам по распознаванию преступлений на почве антисемитской ненависти и обращению с их жертвами. В прилагаемых к нему документах содержится краткое объяснение иудаизма и еврейских праздников, которые важно знать, чтобы находиться в состоянии повышенной бдительности. В руководстве также приводится сводная таблица, в которой приведены рекомендации в том числе парламентариям, религиозным лидерам и лидерам гражданского общества. Кроме того оно содержит «рабочее определение» антисемитизма. Руководство было переведено и в настоящее время доступно на тринадцати языках.

Не менее важно, что руководство является официальным изданием ОБСЕ и БДИПЧ. Оно следует с принятым государствами-участниками международным обязательствам, зафиксированным в многочисленных решениях Совета министров. Это открывает уникальную возможность в сотрудничестве с конкретными правительствами для непосредственного включения руководства и приводимых в нем примеров в национальные программы подготовки сотрудников правоохранительных органов. Оно также является важной частью плана программы «От слов к делу», которая также получает финансовую поддержку за счет внебюджетных средств.

Разработка и публикация руководства по безопасности стало важным этапом в усилиях ОБСЕ по решению самой неотложной проблемы, стоящей перед еврейскими общинами. Те сотрудники БДИПЧ, которые занимались его разработкой, готовились к активному включению руководства в программы подготовки сотрудников правоохранительных органов во всем регионе ОБСЕ. Однако БДИПЧ расторгло контракт с группой специалистов, нанятых для проекта «От слова к делу» по борьбе с антисемитизмом, с целью перенаправить оставшиеся внебюджетные средства на новый, более общий проект по борьбе с различными проявлениями нетерпимости, в том числе с антисемитизмом. Когда стало ясно, что эти средства не могут быть направлены на иные цели, было запланировано несколько новых программ подготовки кадров, однако долгосрочные планы остались без изменений.

\section{Определение антисемитизма}

Первый шаг в борьбе с антисемитизмом - это его определение.

Антисемитизм может быть формой расизма и ксенофобии, но он также бросает вызов нашим общим представлениям о нетерпимости. Он присутствует и там, где есть значительные еврейские общины, и там, где практически нет евреев. Неважно, являются ли евреи новоприбывшими, подобно другим группам иммигрантов, или 
они жили в странах на протяжении веков. Теории заговора могут бросить вызов любой логике - евреи одновременно стоят за коммунизмом и капитализмом, - но это нисколько не мешает их распространению. Вековые антисемитские метафоры можно легко приспособить к современным обстоятельствам. Евреев обвиняли в распространении чумы в средневековье; сейчас они стоят за сегодняшней пандемией коронавируса. Когда-то евреям приписывали убийства христиан ради крови, необходимой им для их ритуалов; теперь этот древний кровавый навет экстраполируется на обращение Израиля с палестинцами. Холокост, несомненно, является самым документально подтвержденным геноцидом в современную эпоху; однако есть те, кто отрицает его или его масштабы. Они делают это не из интереса к исторической достоверности, а как еще одно средство причинения боли тем, кто пережил Холокост, и их собратьям.

Необходимость уметь описать и передать это сложное понимание антисемитизма и многочисленных форм, которые он может принимать, часто упоминалась участниками конференций ОБСЕ по антисемитизму в 2003 и 2004 годах. С этой целью по приглашению директора ЕЦМРК осенью 2004 года некоторые из нас собрались вместе, чтобы разработать новое, всеобъемлющее определение антисемитизма. Я был там в качестве директора по международным еврейским делам Американского Еврейского Комитета. В состав нашей рабочей группы входили представители европейских еврейских организаций, Европейской комиссии Совета Европы по борьбе с расизмом и нетерпимостью (ЕКРН), а также недавно созданного БДИПЧ департамента ТНД. В январе 2005 года было достигнуто консенсусное соглашение, а в марте были обнародованы результаты, которые стали известны как «рабочее определение антисемитизма ЕЦМРК». Задуманное в просветительских целях для правительств и гражданского общества, оно включало в себя набор очевидных примеров антисемитизма, в том числе связанных с Израилем. Когда работа завершилась, и рабочее определение антисемитизма ЕЦМРК было опубликовано, БДИПЧ включило его в учебный материал своих новых программ подготовки сотрудников полиции в области борьбы с преступлениями на почве ненависти.

Рабочее определение ЕЦМРК привлекло значительное внимание как сторонников, так и недоброжелателей, включив в него примеры антисемитизма в отношении государства Израиль. Высказывалась обеспокоенность по поводу того, что его можно использовать против критиков Израиля, заклеймив их антисемитами, даже несмотря на то, что в определении прямо говорится, что «критику по отношению к Израилю, сходную по степени с критикой по отношению к другим государствам, не следует считать антисемитизмом» ${ }^{54}$. Между тем, лидеры еврейских общин отметили, что антиизраильские демонстрации часто превращались в антисемитские и в некоторых случаях даже приводили к физическим антисемитским нападениям. Однако власти считали их политическими по своему характеру и не рассматривали их как преступления на почве ненависти. Для них эти примеры были в числе самых важных. 
Можно было бы ожидать, что ОБСЕ и БДИПЧ с их обязательствами по борьбе с антисемитизмом будут в авангарде усилий по содействию принятия и использования рабочего определения. И все же, несмотря на заметные действия со стороны некоторых лиц и некоторых государств-участников, результаты их деятельности неоднозначны.

Ряд государств-участников ОБСЕ использовали рабочее определение ЕЦМРК. К ним относятся Соединенное Королевство, которое включило его в свое учебное пособие для курсантов полиции, и Соединенные Штаты, которые использовали его при подготовке первого доклада Госдепартамента по антисемитизму в мире. В 2009 году ЕЦМРК был включен в состав нового и более крупного Агентства ЕС по основным правам (АОП). В марте того же года, в качестве личного представителя действующего Председателя ОБСЕ, я созвал в Вене круглый стол под председательством Греции и в сотрудничестве с БДИПЧ, на который собрались лидеры еврейских общин в регионе ОБСЕ. На встрече также присутствовал вновь назначенный директор АОП. Те еврейские лидеры, которые высоко оценили «рабочее определение», задали ему вопрос, будет ли АОП продолжать его продвигать и если да, то каким образом. Хотя несколько лет спустя директор АОП примет решение, что в мандат АОП не входит давать определения антисемитизма или любых других форм нетерпимости, на круглом столе он сказал участникам, что они и дальше смогут использовать это определение. Как он и заверил, рабочее определение было сохранено на веб-сайте АОП, но в отличие от других документов, которые были переданы в юрисдикцию нового агентства, рабочее определение антисемитизма было размещено под старым логотипом ЕЦМРК.

В 2013 году АОП полностью удалило рабочее определение ЕЦМРК со своего сайта, заявив, что это стало частью программы широкой очистки сайта и напомнив, что формулирование определений входит в круг его задач. Оно заняло позицию, согласно которой меньшинства и другие группы жертв должны сами определять предрассудки, с которыми они сталкиваются. АОП также отметило, что проведенный им в ЕС опрос о столкновениях евреев с проявлениями антисемитизма и восприятии ими этого явления включал проявления антисемитизма в отношении Израиля в качестве одного из примеров, который респонденты могли выбрать. Этот выбор оказался одним из самых популярных среди опрошенных ${ }^{55}$. Несмотря на то, что в то время оно являлось институциональным «сиротой», рабочее определение ЕЦМРК по-прежнему рекомендовалось государствам для понимания многомерного характера антисемитизма, и его использовало все большее число государств-участников ОБСЕ.

На конференции ОБСЕ «Берлин плюс десять» в ноябре 2014 года действующий Председатель от Швейцарской Конфедерации сделал конкретную ссылку на рабочее определение в своем резюме выводов встречи, заявив, что:

«рабочее определение антисемитизма, распространенное Европейским мониторинговым центром по вопросам расизма и ксенофобии в 2005 году и используемое 
мониторинговыми организациями в различных государствах-участниках ОБСЕ, по-прежнему представляет собой полезный инструмент, помогающий государственным органам и гражданскому обществу объяснять, каким образом антисионизм часто используется как прикрытие для антисемитизма, а еврейские общины часто становятся объектом, на который изливается враждебное отношение к Израилю» ${ }^{56}$.

В январе 2015 года я присутствовал на встрече специальных посланников в Праге. Несколько стран, включая Чешскую Республику, Соединенное Королевство, Соединенные Штаты и Германию, назначили специальных посланников по борьбе с антисемитизмом. Европейская комиссия незадолго до этого назначила специального координатора по этому вопросу. За столом переговоров была новый директор департамента ТНД БДИПЧ. Хотя дискуссия носила широкий характер, но в ней также присутствовал и оживленный обмен мнениями о рабочем определении и путях его продвижения и использования. Когда каждый из участников рассказывал о том, что предпринимается в их странах и организациях, я с удивлением услышал заявление директора ТНД о том, что БДИПЧ не может использовать рабочее определение, если не получит консенсусного одобрения всех государств-участников ОБСЕ. Разве она не знала, что два ее предшественника уже использовали рабочее определение в подготовленных ими материалах? Разве недавние рекомендации действующего Председателя ОБСЕ не были достаточным основанием?

Когда в 2016 году Германия приняла председательство в ОБСЕ, она сделала борьбу с антисемитизмом одним из своих приоритетов. В качестве личного Представителя я тесно сотрудничал с главой целевой группы ОБСЕ и со специальным представителем министерства иностранных дел по связям с еврейскими организациями и вопросам, касающимся антисемитизма, послом Феликсом Кляйном. Кроме того, собравшись в мае 2016 года в Бухаресте, Международный альянс памяти жертв Холокоста (МАПХ), - организация, на тот момент насчитывавшая своими членами 31 государство, - принял первоначальное рабочее определение антисемитизма ЕЦМРК с незначительными правками. Отныне у него снова был свой дом, и с тех пор оно известно как рабочее определение антисемитизма Международного альянса в память о Холокосте. К концу года немецкое председательство ОБСЕ планировало утвердить рабочее определение решением Совета министров.

В течение весны и лета 2016 года Германия предпринимала активные усилия по обеспечению поддержки со стороны государств-участников. Она сделала соответствующие представления послам в Берлине и провела специальное совещание с представителями государств-участников в Берлине. Она стремилась заручиться поддержкой всех государств-членов ЕС, с тем чтобы их послы в ОБСЕ в Вене выступали единым фронтом. Когда мы услышали, что у правительства Дании имеются оговорки, посол Кляйн и я совершили специальную поездку в Копенгаген. Мы полагали, что у них есть проблемы с примерами антисемитизма, приведенными в рабочем определении, касающимися Израиля, и разработали стратегию по их решению. Но мы ошибались. Министерству иностранных дел Дании нужно было убе- 
диться в том, что Германия действительно хочет этого решения, и действующий Председатель имел в виду то, что он сказал (он действительно имел это в виду). Как только это было подтверждено, Дания присоединилась к нам.

Однако в ходе этой кампании мы поняли, что никто еще не подготовил проект предлагаемого решения. Никто не хотел, чтобы государства-участники в ходе работы над решением начали редактировать рабочее определение, вносить в него добавления или удалять какие-то положения. Поэтому в начале сентября был подготовлен проект решения, в котором предлагалось принять рабочее определение антисемитизма, данное Международным альянсом памяти жертв Холокоста со ссылкой на определение, данное на сайте альянса. Таким образом, текст определения и его примеры не могли быть подвергнуты редактированию. По мере приближения к совещанию по рассмотрению выполнения обязательств, посвященного человеческому измерению, мы были довольно оптимистичны в отношении достижения консенсусного соглашения.

Но мы не учли Российскую Федерацию, которая до сих пор отказывала в поддержке. Пытаясь понять их возражения, я встретился с российской делегацией на совещании по рассмотрению выполнения обязательств, посвященного человеческому измерению. Они выразили две озабоченности по поводу проекта решения. Вопервых, поскольку Россия не являлась членом Международного альянса памяти жертв Холокоста, они возражали против решения, в котором давалась ссылка на принятое альянсом определение (Многие государства-участники ОБСЕ также не являются его членами). Во-вторых, они заявили, что российские еврейские эксперты не согласны с данным определением (до этого момента я ничего не слышал об этом от российских еврейских лидеров). Я спросил, были ли это их единственные две проблемы. В ответ мне сказали: «Да, пока что». Трудно было не прийти к выводу, что, если понадобится новая проблема, они ее найдут.

В октябре Российский еврейский конгресс организовал в Москве международную конференцию по противодействию антисемитизму. Зная о предстоящих дебатах по решению ОБСЕ, он принял резолюцию, в которой российские еврейские лидеры официально утвердили принятое рабочее определение ${ }^{57}$, тем самым была устранена, по крайней мере, одна из причин.

По прибытии в Гамбург накануне декабрьского Совета министров в 2016 году у нас было мало оптимизма. Большинство проектов решений не получили консенсусной поддержки, и решение о принятии рабочего определения было среди них. Поздним вечером состоялась встреча министра иностранных дел России Сергея Лаврова с действующим Председателем Франком-Вальтером Штайнмайером, на которой обсуждался вопрос о возможности достижения определенной договоренности. Ранним утром следующего дня посол Кляйн сообщил мне, что у него были хорошие новости. В то время как другие проекты решений оставались в тупике, кажется, существовала возможность достижения соглашения о поддержке рабочего определения. Мы были - по крайней мере в течение нескольких часов - в приподнятом настрое- 
нии. Два министра достигли договоренности о том, что Россия поддержит решение, если будут внесены два скромных изменения: способ упоминания Международного альянса в тексте и дополнительная формулировка, указывающая на то, что принятие определения ОБСЕ следует рассматривать как первый шаг на пути к достижению глобального консенсуса. Мы не видели проблем с принятием этих изменений, когда собрались на утреннюю редакционную сессию. Но когда российская делегация взяла слово, чтобы предложить изменения, их было не два, а много, включая существенную новую формулировку и полное удаление важной ссылки на рабочее определение антисемитизма альянса. Было ясно, что компромиссов быть не может, а сам министр Лавров в это время уже летел обратно в Москву. Проект решения был снят с рассмотрения.

В 2017 году австрийское председательство предприняло еще одну попытку добиться принятия рабочего определения на встрече Совета министров ОБСЕ. Однако в течение года стало очевидно, что мы по-прежнему находились в тупике, в котором оказались в 2016 году. Мы неохотно пришли к выводу, что вторая безуспешная попытка может оказаться контрпродуктивной. Несмотря на очевидную поддержку со стороны подавляющего большинства государств-участников, повторная неудача на Совете министров давала повод другим государствам утверждать, что следует ограничить применение рабочего определения. Как отмечалось выше, рабочее определение включено в приложение к руководству БДИПЧ ОБСЕ «От слова к делу» по безопасности еврейских общин, а также в руководящие принципы для разработчиков политики по противодействию антисемитизму при помощи образования ${ }^{58}$. Однако оно не является центральным компонентом этих руководств, как это было в ранней программе обучения сотрудников полиции БДИПЧ.

В то же время другие международные организации и отдельные правительства добились значительного прогресса в принятии рабочего определения и рекомендовали применять его. В декларации Европейского совета 2018 г. содержится призыв к государствам-членам ЕС принять его ${ }^{59}$. В своем первом докладе об антисемитизме в 2019 году Специальный докладчик ООН по вопросу о свободе религии и убеждений призвал членов $\mathrm{OОН}$ к его использованию и переизданию ${ }^{60} . \mathrm{C}$ тех пор даже Агентство ЕС по основным правам восстановило текст рабочего определения на своем сайте и официально опрашивает все государства-члены ЕС о том, как они используют его в своих национальных планах по противодействию антисемитизму. В 2020 году Германия стала председателем Международного альянса памяти жертв Холокоста, а во второй половине года - председателем Совета ЕС и обязалась продолжать уделять пристальное внимание борьбе с антисемитизмом. 


\section{Вызовы, связанные со структурой и методами работы ОБСЕ}

Процесс принятия решений ОБСЕ на основе консенсуса затрудняет принятие быстрых и решительных мер. Он не только затрудняет принятие министерских решений, что хорошо известно, но и может стать препятствием или, что еще хуже, использоваться в качестве предлога теми, кто имеет право принимать решения, но не пользуется им. Действующий Председатель имеет полномочия организовать конференцию экспертов или поддержать официальный визит личного представителя. Старшие сотрудники БДИПЧ обладают значительной свободой в рекомендациях докладчиков или составлении аннотированной повестки дня. Однако задержки или бездействие это не только результат желания привлечь союзников к этому процессу. Иногда это лишь реакция на ожидаемую критику, которая может даже не последовать.

То, что со временем превратилось в «обычную практику» ОБСЕ, также замедляет или ослабляет ее усилия. Послы в Вене часто говорят о применении «целостного» подхода, настаивая на том, что борьба с антисемитизмом должна быть частью более широких усилий по борьбе с нетерпимостью. То, что на первый взгляд может показаться благородной и принципиальной позицией, затрудняет признание конкретных проявлений элементов антисемитизма и особых проблем, с которыми сталкиваются еврейские общины. Кроме того, законный интерес ОБСЕ к географическому балансу не всегда способствовал проведению более качественных конференций или наиболее эффективных визитов. Проблема антисемитизма, размеры и проблемы еврейских общин, а также присутствие признанных экспертов неравномерно распределены по всему региону ОБСЕ.

Каждое председательство в ОБСЕ определяет свои приоритеты на год. Некоторые уделяли больше внимания борьбе с антисемитизмом, чем другие, хотя никто из моих коллег, исходя из моего опыта, не проигнорировал эту проблему. Это, конечно же, влияет по крайней мере на конкретные программы, экспертные конференции и решения, которые предлагает председательство. Посол Штрохал поднял вопрос о необходимой поддержке, которая потребуется БДИПЧ для выполнения поставленных перед ним задач. Полагаю, что на этот вопрос был дан ответ: были и есть государства-участники, готовые помочь. Однако значение директора БДИПЧ и его личных усилий невозможно переоценить. Внимание и активность одного из директоров привели к новаторской работе, оказавшей значительное влияние на борьбу с антисемитизмом. Безразличие другой помешало усилиям даже тогда, когда председательство БДИПЧ требовало приложить больше усилий.

Несмотря на предложения ключевых государств-участников поддержать будущие программы БДИПЧ, направленные на противодействие антисемитизму, директор оставалась тверда в своем решении продолжать поиск внебюджетных средств исключительно для гораздо более широкой и более универсально ориентированной программы «От слов к делу». Уход высокопоставленных сотрудников департамента по вопросам толерантности и недискриминации и вакантная должность эксперта- 
консультанта по вопросам противодействия антисемитизму в БДИПЧ в этом году еще больше замедлили их усилия.

\section{Перспективы на будущее}

Премьер-министр Швеции Стефан Лёвен планировал провести в октябре 2020 года в Мальмё международную конференцию, на которой особое внимание было бы уделено противодействию антисемитизму. Это также предоставило бы возможность отметить двадцатую годовщину Стокгольмской конференции, которая положила начало Международному альянсу памяти жертв Холокоста. В январе 2020 г. Лёвен полностью одобрил рабочее определение МАПХ, которое стало бы отправной точкой и для других участников конференции ${ }^{61}$.

Ожидалось также, что будут особо выделены проблемы безопасности, с которыми сталкиваются еврейские общины, поскольку они представляют собой серьезное испытание для еврейской общины Мальмё. После террористического нападения на синагогу в Копенгагене в 2015 году правительство Дании тесно сотрудничало со скандинавскими еврейскими специалистами по безопасности в целях разработки нового, основанного на сотрудничестве подхода, который получил высокую оценку и от бывших критиков. Новая модель передового опыта была готова к распространению.

Хотя пандемия коронавируса привела к переносу конференции на октябрь 2021 г., по случайному совпадению она пройдет в год председательства Швеции в ОБСЕ. Из этого следует, что Швеция сделает противодействие антисемитизму ключевым компонентом своей программы председательства, а также получит возможность воспользоваться ресурсами БДИПЧ. Новый директор БДИПЧ и новое профессиональное руководство в департаменте по вопросам толерантности и недискриминации могут оказать реальную помощь. С помощью и при поддержке других государств-участников мы можем стать свидетелями того, как ОБСЕ снова возьмет на себя ведущую роль в противодействии антисемитизму.

Антисемитизм иногда называют древнейшей в мире ненавистью. К сожалению, с ним все еще приходится иметь дело в настоящем.

\section{Примечания}

43 OSCE Conference on Anti-Semitism. Berlin, 28 and 29 April 2004. Consolidated Summary. OSCE Document PC.DEL/696/04/Rev/1. 27 July 2004. URL: https://www.osce.org/files/f/docu ments/e/f/35389.pdf.

44 Председатель: Болгария. Действующий председатель. Документ ОБСЕ PC.DEL/347/04, 29 апреля 2004 г. URL: https://www.osce.org/files/f/documents/8/a/31436.pdf. 
Там же. С.3.

46 Manifestations of Antisemitism in the EU 2002 - 2003 Based on information by the National Focal Points of the EUMC - RAXEN Information Network. - Vienna: European Monitoring Centre on Racism and Xenophobia, 2004. URL: https://fra.europa.eu/sites/default/files/fra_uploa ds/184-AS-Main-report.pdf.

47 Там же. С. 242.

48 Antisemitism Overview of data available in the European Union 2008-2018. European Union Agency for Fundament al Rights. - Luxembourg: Publications Office of the European Union, 2019. URL: https://fra.europa.eu/sites/default/files/fra_uploads/fra-2019-antisemitism-overview2008-2018_en.pdf.

49 Country Reports - Personal Representative of the Chairperson-in-Office on Combating AntiSemitism // Официальный сайт ОБСЕ. URL: https://www.osce.org/chairmanship/333786.

50 Summary Report of the Expert Conference on Addressing the Security Needs of the Jewish Community in the OSCE Region: Challenges and Good Practices, 13 June 201, Berlin, Germany. OSCE ODIHR. URL: https://www.osce.org/files/f/documents/5/c/105253.pdf.

51 Final Report. 10th Anniversary of the OSCE's Berlin Conference on Anti-Semitism: High-Level Commemorative Event and Civil Society Forum, 12-13 November 2014, Berlin, Germany.URL: https://www.osce.org/files/f/documents/e/f/136561.pdf.

52 10th Anniversary of the OSCE's Berlin Conference on Anti-Semitism High-Level Commemorative Event Berlin, 12-13 November 2014. Swiss OSCE Chairmanship conclusions. URL: https://www.osce.org/files/f/documents/9/0/126710.pdf.

53 Понимание сути преступлений на почве антисемитизма и обеспечение потребностей еврейских общин в сфере безопасности. Практическое руководство. - Варшава: БДИПЧ ОБСЕ, 2018. URL: https://www.osce.org/files/f/documents/c/e/365556.pdf.

54 Working definition of Antisemitism // International Holocaust Remembrance Alliance. URL: https://www.holocaustremembrance.com/working-definition-antisemitism. Текст рабочего определения на русском языке см.: Понимание сути преступлений на почве антисемитизма и обеспечение потребностей еврейских общин в сфере безопасности. С. 86-88.

55 FRA survey of Jewish people's experiences and perceptions of antisemitism, 23 March 2012 URL: https://fra.europa.eu/en/publication/2012/fra-survey-jewish-peoples-experiences-and-perce ptions-antisemitism\#TabPubRelated.

56 10th Anniversary of the OSCE's Berlin Conference on Anti-Semitism High-Level Commemorative Event Berlin, 12-13 November 2014. Swiss OSCE Chairmanship conclusions.

57 Декларация Первой Московской международной конференции по противодействию антисемитизму «Защитим будущее». Москва, 2 ноября 2016 года. URL: http://mcca.ru/ru/news/1 5.

58 Противодействие антисемитизму при помощи образования: Руководящие принципы для разработчиков политики. - Париж; Варшава: ЮНЕСКО; БДИПЧ ОБСЕ, 2019. С. 97-98. URL: https://www.osce.org/files/f/documents/7/1/420140.pdf.

59 Council Declaration on the fight against antisemitism and the development of a common security approach to better protect Jewish communities and institutions in Europe - Council conclusion (6 December 2018). URL: https://data.consilium.europa.eu/doc/document/ST-15213-2018-INIT/en/ pdf.

60 Доклад Специального докладчика по вопросу о свободе религии или убеждений, 20 сентября 2019 года. С. 26. URL: https://undocs.org/ru/A/74/358.

61 Swedish Prime Minister calls on world to fight for memory of the Holocaust // The Government of Sweden. 2020. 22 January. URL: https://www.government.se/opinion-pieces/2020/01/opinion -piece/. 
